\title{
Forecast of Distribution and Thickness of Gas Hydrate Stability Zone at the Bottom of the Caspian Sea
}

\author{
Vasily Bogoyavlensky *, Alisa Yanchevskaya and Aleksei Kishankov \\ Oil and Gas Research Institute of the Russian Academy of Sciences (OGRI RAS), 3 Gubkina St., \\ 119333 Moscow, Russia; alisa.yanchevskaya@mail.ru (A.Y.); alexey137k@yandex.ru (A.K.) \\ * Correspondence: vib@pgc.su; Tel.: +7-499-1350681
}

Citation: Bogoyavlensky, V.

Yanchevskaya, A.; Kishankov, A.

Forecast of Distribution and

Thickness of Gas Hydrate Stability

Zone at the Bottom of the Caspian

Sea. Energies 2021, 14, 6019. https://

doi.org/10.3390/en14196019

Academic Editor: Jean Vaunat

Received: 15 July 2021

Accepted: 17 September 2021

Published: 22 September 2021

Publisher's Note: MDPI stays neutral with regard to jurisdictional claims in published maps and institutional affiliations.

Copyright: (c) 2021 by the authors. Licensee MDPI, Basel, Switzerland. This article is an open access article distributed under the terms and conditions of the Creative Commons Attribution (CC BY) license (https:// creativecommons.org/licenses/by/ $4.0 /)$.

\begin{abstract}
The Caspian Sea is a region of active hydrocarbon production, where apart from conventional accumulations, gas hydrates $(\mathrm{GH})$ are known to exist. $\mathrm{GH}$ are a potential future source of energy, however, currently they pose danger for development of conventional fields. The goal of this research was to determine the area of GH distribution and thickness of their stability zone in the Caspian Sea using numerical modeling and to define how certain parameters affect the calculated thickness. As a result of the research, cartographic schemes were created for the South and Middle Caspian, where GH were predicted. For the South Caspian, conditions for methane hydrates formation exist at depths of more than 419-454 m, and for the Middle Caspian, more than 416-453 m. The maximal thicknesses of methane hydrates stability zones for the South Caspian can reach 900-956 m, and for the Middle Caspian, 226-676 m. Variations of parameters of seafloor depth, geothermal gradient and gas composition can significantly change the resulting thickness of GH stability zone.
\end{abstract}

Keywords: Caspian Sea; geohazards; gas hydrates; methane; methane hydrate systems; thickness of hydrates stability zone; thermobaric conditions; numerical modeling

\section{Introduction}

At the present time of active exploration of conventional sources of hydrocarbons (HC) - oil and gas accumulations in highly-permeable reservoirs - certain countries are exploiting unconventional sources of fuel, e.g., shale gas and coalbed methane [1,2]. The attention of scientists from all over the world is particularly attracted to gas hydrates (GH), as they contain significantly more reserves of gas in comparison with that of conventional accumulations [3,4]. GH are solid compounds of gas and water, formed under specific thermobaric conditions-moderate-to-high pressures and low temperatures (for $0{ }^{\circ} \mathrm{C}$ in saline water, the pressure should exceed $3 \mathrm{MPa}$ ) $[3,4]$. Such conditions exist in northern territories with distribution of permafrost (PF) and in deep offshore areas.

In Russia, and formerly, the Soviet Union, gas was produced on the Messoyakha Field $\left(69.129^{\circ} \mathrm{N}, 82.51^{\circ} \mathrm{E}\right)$ from the accumulation in the Arctic criolithosphere [5,6]. The field was discovered in 1967 in the north of the Krasnoyarsk Region, $230 \mathrm{~km}$ to the west from Norilsk. In the upper part of the accumulation, gas is in hydrated state, whereas in the lower part, it is in free state. During gas production from the lower part, decreasing formation pressure is accompanied by significant $\mathrm{GH}$ dissociation.

Therefore, GH are important as a future energy source, however economically efficient technologies of gas production from hydrate-saturated formations are not yet developed [7,8]. GH currently pose a potential danger for well drilling during development of conventional HC fields, as their uncontrolled dissociation reduces stability of sediments [9-14]. For well drilling, gas-saturated reservoirs under GH are particularly dangerous in terms of possible gas blowouts and explosions, as the sealing role of GH contributes to formation of free gas accumulations with high pressure $[9,14]$. GH caused negative influence at different stages of the development of the catastrophe in the Gulf of 
Mexico with destruction of the Deepwater Horizon platform and death of $11 \mathrm{crew}$ members [15]. The high danger of gas blowouts from cryolithosphere exists for development of fields on the Arctic land, particularly, on the Yamal Peninsula [6].

In addition, dissociation of GH can contribute to global climate warming, since methane is a strong greenhouse gas $[16,17]$. This is particularly important for the Arctic land and shallow offshore areas, where GH can exist on smaller depths of seafloor due to low temperatures of near-bottom water, and as result of dissociation, gas can partially reach the atmosphere $[18,19]$.

Wide distribution of GH deposits in many deep areas of the World Ocean, including the continental slope of the Arctic Ocean, the Gulf of Mexico, the Norwegian, Black, Okhotsk, and Caspian seas, and the bottom of the Lake Baikal was also proven by direct exploration methods, as well as predicted based on indirect data $[4,9,20-36]$.

In 2018, the authors of this article made a forecast of distribution of sub-bottom GH in the Arctic Ocean and adjacent offshore areas above the $45^{\circ}$ latitude based on the analysis of the extensive water temperature database of the National Oceanic and Atmospheric Association (NOAA) [25,26]. In 2019 and 2020, the experience of this work was implemented for studying the Caspian and Black seas, where GH was discovered in drilled wells $[28,29]$.

In the Caspian Sea, favorable thermobaric conditions (pressure and temperature) for formation and existence of GH are present in the areas of the Derbent (Middle CaspianMC) and Lankaran (South Caspian-SC) depressions [28,37,38], where the maximum sea depths reach 788 and $1025 \mathrm{~m}$, respectively. In the areas of the MC and SC, there are deep basement depressions (more than 15 and $20 \mathrm{~km}$, respectively), in which the sedimentary fillings have a high oil and gas potential. In particular, a number of large and unique HC fields in terms of reserves were discovered in the SC (Neft Dashlary, Azeri-ChiragGuneshli, Shakh Deniz, and others), and in the MC, in 2002, the large Central oil and gas condensate field was discovered [39].

The actual existence of GH was first proved in the southern part of the area (SC) in 1979 at a depth of $480 \mathrm{~m}$ on the summit of the Shatsky Rise in the area of an active mud volcano. An intensively degassing piece of clastic-carbonate sediment containing large (up to $5 \mathrm{~cm}$ ) fragments of GH was raised by a bottom grab [20].

As a result of subsequent expeditionary studies at the bottom of the Caspian Sea, the SC GH-bearing submarine mud-volcanic province was distinguished [30], accumulations of GH were discovered, named Buzdag (associated with the Buzdag mud volcano on the Shatsky Rise), Elm (depth ca. $560 \mathrm{~m}$, diameter ca. $4 \mathrm{~km}$ ), and the occurrence of GH on the Abikh Rise was revealed [32,40].

The significant GH potential of the SC is additionally confirmed by numerous studies $[30,31,33,37,40-42]$, which show that the formation of GH is possible not only near mud volcanoes, but also in the sedimentary layers. However, despite a fairly large amount of actual materials, the upper part of the sedimentary cover of the Caspian Sea, especially in the MC region, is insufficiently studied. The results of direct exploration for GH in the MC are not found in the published materials.

As the Caspian Sea is a rich oil and gas bearing region, the issue of GH distribution is currently important, concerning estimation of near-surface sediments stability for constructing the infrastructure objects, and also prevention of accidental situations during well drilling.

As a result of the first stage of studies of potential GH content of the Caspian Sea, the authors created schemes of bottom water temperatures and predicted distribution of GH (assumed gas composition was pure methane) within the areas of the MC and SC [28]. The purpose of the present research (the second stage of studies) is to clarify the zones of potential distribution of GH based on new data and to calculate the possible thickness of the GH stability zone (GHSZ). Apart from this, the important goal of the research is to understand how certain parameters, assumed for calculations, affect the thickness of 
GHSZ, which is substantial for forecasts of GH potential of other different regions of the world, particularly, offshore areas of the Arctic.

\section{Materials and Methods}

For the existence of GH, favorable thermobaric conditions are required, which can be predicted using numerical modeling. For calculations of equilibrium curves of hydrate formation (thermobaric conditions of GH stability), the open-access CSMHYD software [43-45], produced on basis of empirical equations in the Centre for Hydrate Research of the Colorado School of Mines (Golden, CO, USA), was used. On basis of assigned parameters of temperature, hydrate-forming gas composition, and water salinity, the CSMHYD software calculates the minimal value of pressure, necessary for the occurrence of GHSZ, from which the minimal seafloor depth is further derived.

The base of GHSZ is defined by the intersection of the equilibrium hydrate formation curve and the reservoir temperature change curve $[4,21]$, which can be numerically calculated based on the known geothermal gradient (GG), which depends on the heat flow.

The forecast of GHSZ distribution and its thickness was based on the data obtained from open sources: bottom depth (pressure)—from bathymetric data of GEBCO [46]; near-bottom water temperature $(\mathrm{T})$ and salinity $(\mathrm{S})$ - from the World Ocean Database 18 (WOD18) of NOAA [47]; GG in the upper part of the sedimentary cover-from the available publications [48-52].

WOD18 database included 21,882 temperature and salinity measurement stations in the Caspian Sea as of 15 April 2021 [47]. Based on the GEBCO bottom depth database [46], confined to the current level of the Caspian Sea (28 m with regard to the level of the World Ocean), those temperature and salinity measurements were selected which were close to the actual bottom by not less than $10 \%$ of the depth. After that, the input data was reduced by three times and consisted of 6853 stations (6799-measurements of T; 6754-measurements of S), which is significantly more than at the first stage of work in 2019 [28], when the number of near-bottom temperature measurements was 1725.

GG for the SC and MC differ significantly due to different histories of sedimentation and thicknesses of sedimentary cover. The heat flow in the Lankaran Depression mainly varies from $30-80 \mathrm{~mW} / \mathrm{m}^{2}$ (on average, about $40 \mathrm{~mW} / \mathrm{m}^{2}$ ), whereas it has local anomalous peaks in the areas of mud volcanoes and faults $[53,54]$. This depression was formed as a result of rapid subsidence of the basin and high-sedimentation rate (on average, $2 \mathrm{~km} / \mathrm{Ma}$ over the last $5 \mathrm{Ma}$ ) [55]. The heat flow in the central part of the $\mathrm{MC}$ is significantly higher: according to $[53,54]$, it is mainly $60-140 \mathrm{~mW} / \mathrm{m}^{2}$, but locally it even reaches $200 \mathrm{~mW} / \mathrm{m}^{2}$.

The average GG for the upper sedimentary interval $(0-2000 \mathrm{~m})$ of the SC is characterized by abnormally low values of $11-17^{\circ} \mathrm{C} / \mathrm{km}$ (on average, $14^{\circ} \mathrm{C} / \mathrm{km}$ ) [49-51], which is significantly lower than at the Absheron Step $\left(27-34.6^{\circ} \mathrm{C} / \mathrm{km}\right.$ [52]). The average GG for the $\mathrm{MC}$ varies from 18 to $37^{\circ} \mathrm{C} / \mathrm{km}$ [48].

The software used in this research does not consider petrophysical qualities of rocks, such as capillary effects, which also affect the thickness of GHSZ. Besides, the authors did not have data on how these parameters change in the upper part of sedimentary cover. Therefore, analysis of how petrophysical parameters influence the GHSZ thickness would not be justified in this research.

The maps were created in ODV [56] and ArcGIS 10.2 (ESRI) software.

\section{Results}

In the present work (as a second stage of studies), near-bottom water temperatures were updated, and a scheme of near-bottom water salinity was created based on the WOD18 database [47]. The cartographic schemes of distribution of near-bottom water temperatures and salinity are shown in Figure $1 \mathrm{a}, \mathrm{b}$. 

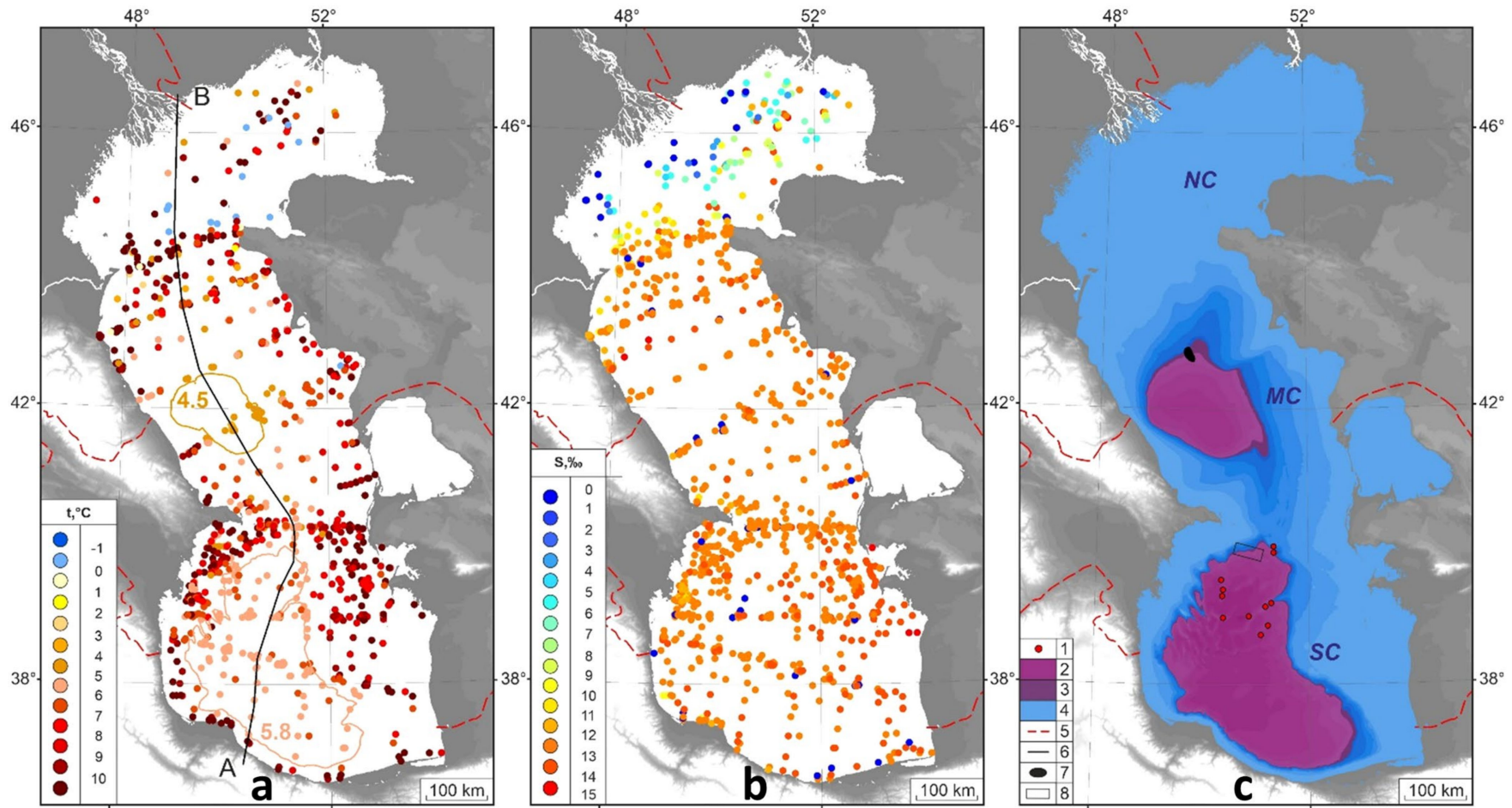

Figure 1. Cartographic schemes of (a) near-bottom water temperatures, (b) salinity, and (c) forecasted gas hydrates (GH) distribution zones in the Caspian Sea. Legend: 1- GH existence confirmed in drilled wells; 2 and 3-zones with favorable thermobaric conditions for GH existence, assuming saline sea (2) and fresh (3) water; 4-absence of conditions for GH existence; 5-state borders; 6-line of temperature section shown in Figure 2; 7 - Central oil and gas condensate field. 8-area of seismic survey around the Absheron Mud Volcano [14,41]; NC—North Caspian, MC—Middle Caspian, SC-South Caspian.

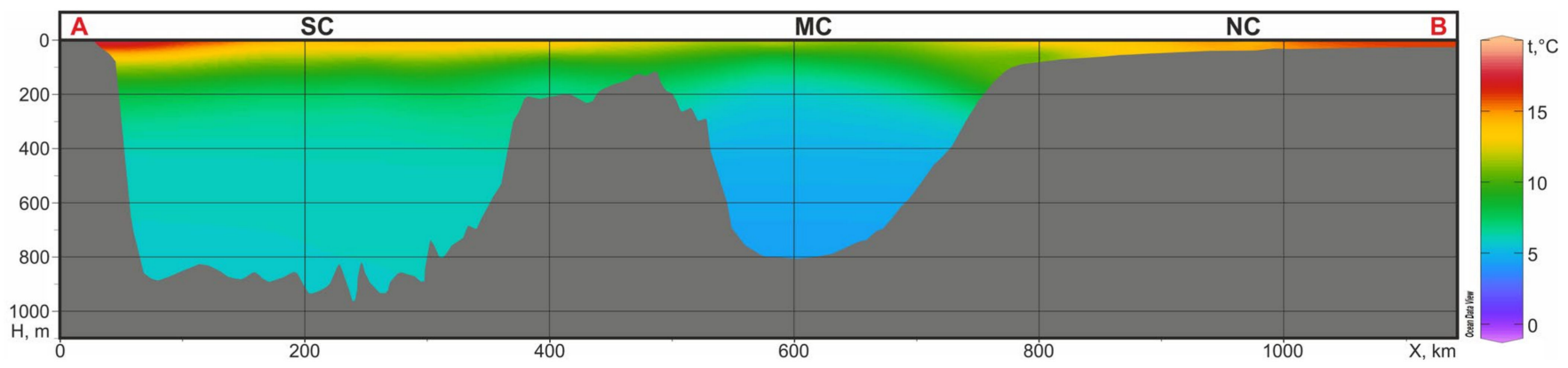

Figure 2. Water temperature section for submeridional line A-B, crossing SC, MC, and NC (location-see Figure 1a).

Figure 2 shows a regional section of the temperatures of the water column along the submeridional line A-B with total length of ca. $1150 \mathrm{~km}$, the location of which is shown in Figure 1a.

According to WOD18 data, in the MC at depths of more than $400 \mathrm{~m}$, near-bottom water temperatures vary from 4 to $5^{\circ} \mathrm{C}$ (Figures $1 \mathrm{a}$ and 2). In the calculations of the GHSZ, the average isotherm of $4.5^{\circ} \mathrm{C}$ at the bottom was used (Figure 3, MC). In the area of the SC at depths of more than $600 \mathrm{~m}$, the average temperatures are close to $5.8^{\circ} \mathrm{C}$ (Figures 1a, 2 and 3, SC). Actual measurements of near-bottom water salinity for both zones vary within close limits-from 12.75 to $13.25 \%$. Figure 4 shows the cartographic schemes of GHSZ thickness, created separately for the minimal (Figure $4 a$ ) and maximal (Figure $4 b$ ) forecasts. 

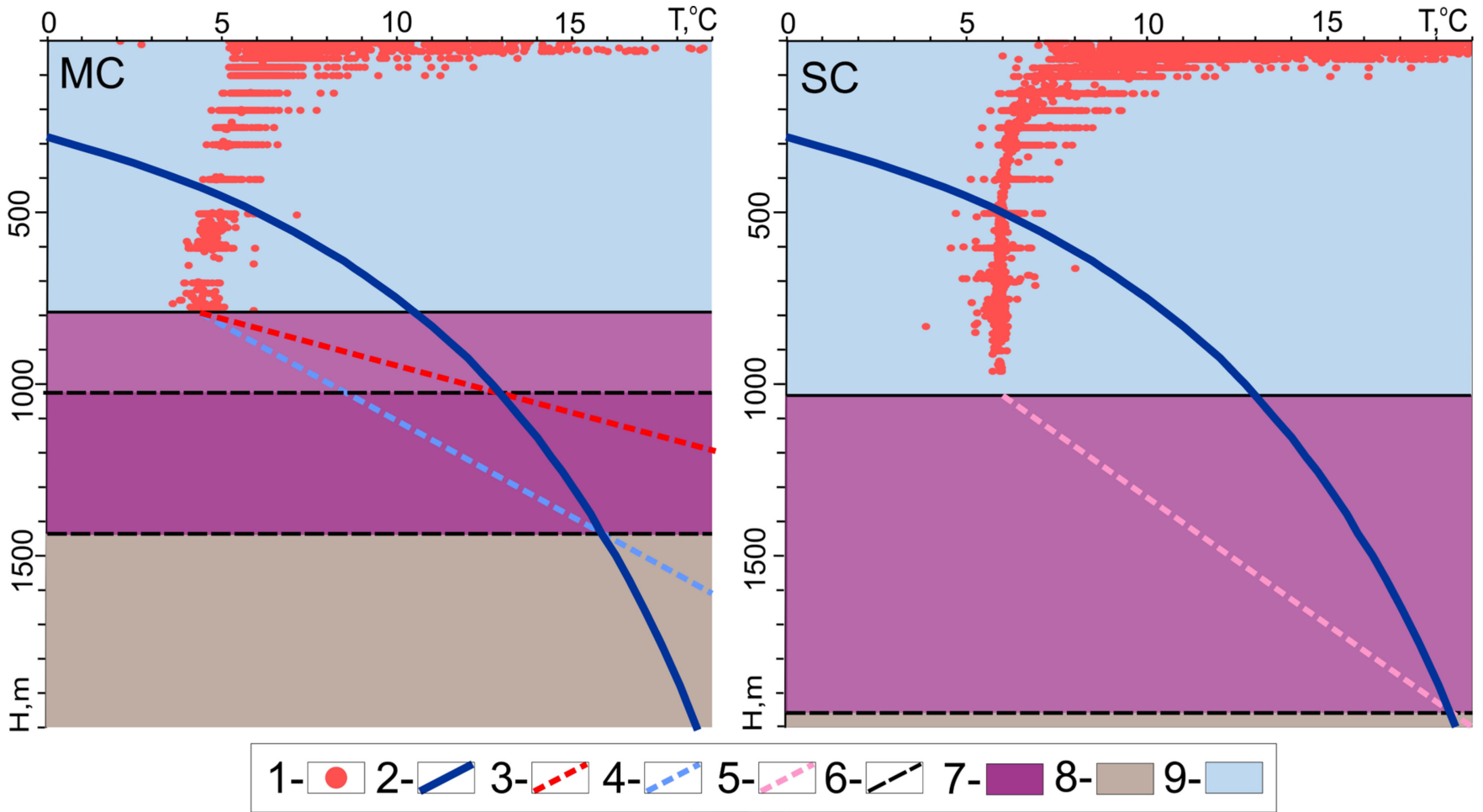

Figure 3. Nomograms of GH stability zones (GHSZ) calculation for MC and SC. Legend: 1-actual measurements of water column temperature in deep area; 2-calculated curve of GH stability for $\mathrm{S}=13 \%$; 3, 4, 5-curves of change of temperature in sediments with geothermal gradients $\left({ }^{\circ} \mathrm{C} / \mathrm{km}\right)$ of 37 (3), 18 (4) and 14 (5); 6-base of GHSZ; 7-GHSZ; 8-absence of GHSZ; 9-water column.

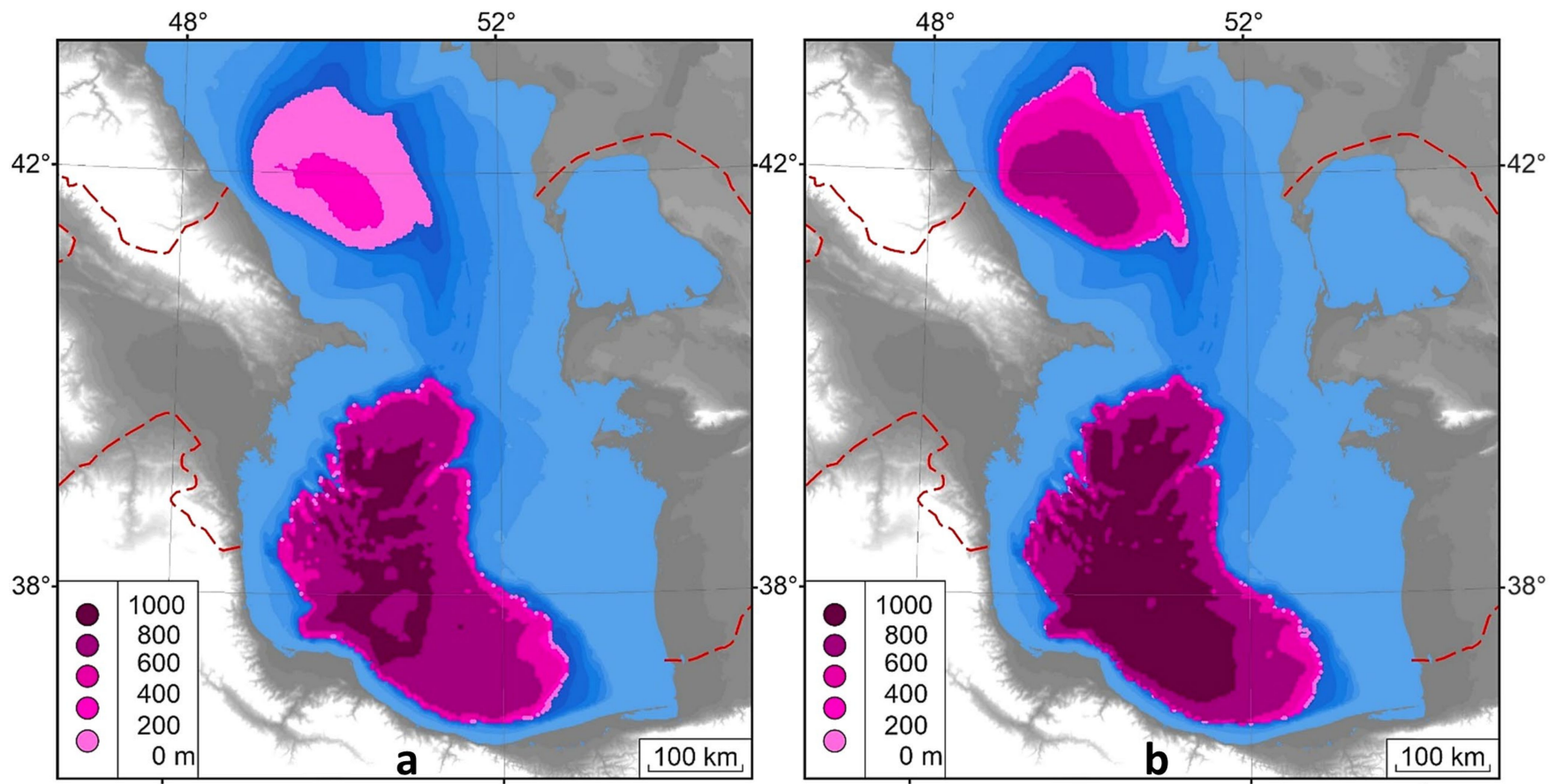

Figure 4. Cartographic schemes of thicknesses of GHSZ for two forecasts: (a) minimal and (b) maximal.

The calculations of the GHSZ (Figure 4) were conducted in the CSMHYD software, assuming $100 \%$ methane gas composition for two models differing in salinity of water in the near-bottom sediments: M1—sea water $(\mathrm{S} 1=13 \%)$; M2-fresh water $(\mathrm{S} 2=0 \%)$. The 
GHSZ for the SC according to the M1 model extends from the sea depth of $454 \mathrm{~m}$, and according to the M2 model, from $419 \mathrm{~m}$. The GHSZ for the MC, according to the M1 model, from $453 \mathrm{~m}$; according to the M2 model, from $416 \mathrm{~m}$ (Figure 1c).

The forecast of GHSZ thicknesses (Figure 4) was made concerning the areal change in the abovementioned parameters for two extreme situations: minimal and maximal. The minimal thicknesses of GHSZ were calculated based on the maximal GG (for $\mathrm{MC}-37^{\circ} \mathrm{C} / \mathrm{km}$, for $\mathrm{SC}-14^{\circ} \mathrm{C} / \mathrm{km}$ ) and the equilibrium stability curve of the M1 model (sea water). The maximal thicknesses of GHSZ were calculated based on the minimal GG (for $\mathrm{MC}-18{ }^{\circ} \mathrm{C} / \mathrm{km}$, for SC $-14^{\circ} \mathrm{C} / \mathrm{km}$ ) and the stability curve of the M2 model (fresh water).

\section{Discussion}

Due to the fact that all calculations are based on $100 \%$ methane gas composition, they are generally conservative (minimized). At the same time, the minimal isobaths of methane hydrates existence obtained in the M2 model for the MC (416 m) and for the SC (419 m) differ from the data from the research of [37] (390 and $480 \mathrm{~m}$, respectively), presumably due to more accurate consideration of physical characteristics of the hydrosphere at the present stage of studies.

According to the calculations (Figure 4), the maximal predicted thickness of GHSZ varies in a range from 900-956 $\mathrm{m}$ in the central part of the Lankaran Depression in the SC. For the MC, in the center of the Derbent Depression, the thickness of GHSZ varies from 226-676 m (Table 1). This allows to conclude that the thickness and distribution of GHSZ are very sensitive to changes in GG and bottom depth (pressure). A decrease in GG and an increase in water depth lead to an increase in thickness of GHSZ. Salinity of pore water and near-bottom water temperatures also play an important role in the fluctuations of GHSZ thickness, but to a lesser extent. The resulting thicknesses of GHSZ, calculated by the authors, are fundamentally different from the data of [37] (for the MC-134 m, 5 times smaller than in the maximal forecast in the present research, and for the SC $-152 \mathrm{~m}$, more than 6 times smaller).

Table 1. Maximal predicted thickness of GHSZ for minimal and maximal forecasts with used parameters.

\begin{tabular}{lccccc}
\hline Forecast & Sea Depth, $\mathbf{m}$ & GG, ${ }^{\circ} \mathbf{C} / \mathbf{k m}$ & Salinity, $\%$ & Area & $\begin{array}{c}\text { Maximal Predicted } \\
\text { Thickness of GHSZ, } \mathbf{m}\end{array}$ \\
\hline $\begin{array}{l}\text { minimal } \\
\text { maximal }\end{array}$ & 788 & 37 & 13 & MC & 226 \\
\hline minimal & 18 & 0 & 13 & SC & 976 \\
maximal & 1025 & 14 & 0 & 956 \\
\hline
\end{tabular}

Current research is the first one that gives the forecast of distribution and stability zone thickness for methane hydrates within the MC and SC, considering areal distribution of near-bottom water temperatures, salinity, and GG, using the reliable CSMHYD software.

In $[14,41]$, GH were predicted based on seismic data, covering an area around the Absheron Mud Volcano. The revealed depth of base of gas hydrates in seismic sections reached $570 \mathrm{~m}$ from the seafloor. This area is located on the edge of the zone with favorable thermobaric conditions for methane hydrates existence, revealed in our research [28] (Figure 1c). However, the mentioned depth of GH base defined in seismic sections [14,41] does not contradict with our study if hydrate-forming gas contains heavy HC along with methane. Also, a map of gas hydrates thickness was created by $[40,57]$ for the SC on basis of seismic data. According to this map, the maximal thickness is about $540 \mathrm{~m}$. However, this research considered GH deposits rather than GHSZ, which should be thicker. Moreover, this map seems to result from interpolation based on few observations of GH base in seismic sections, which could influence the accuracy of the map. 
The presence of heavy HC gases in the composition of the hydrate-forming gas, in addition to methane, expands the range of depths of GHSZ and the boundaries of the area of GH potential existence [4,21,45]. The presence of gas mixtures significantly reduces the sea depth at which formation and existence of GH is possible. In particular, for gases of mixed bacterial-thermogenic genesis from core samples near the Absheron structure [58], concerning fresh water, the minimal required pressure for GHSZ exists at a sea depth of only about $150 \mathrm{~m}[41,59]$. In a number of areas of the SC, gas from GH near mud volcanoes was reported to contain $58.7-87.8 \%$ of methane, with $12.76-40.38 \%$ of heavy $\mathrm{HC}$ gases [60]. According to calculations in CSMHYD software [44], minimal sea depths where GH can exist with such a gas composition are ca. 150-260 m (assuming heavy HC gas is ethane, formation water is fresh, near-bottom water temperature is $5.8^{\circ} \mathrm{C}$ ) (Figure 5).

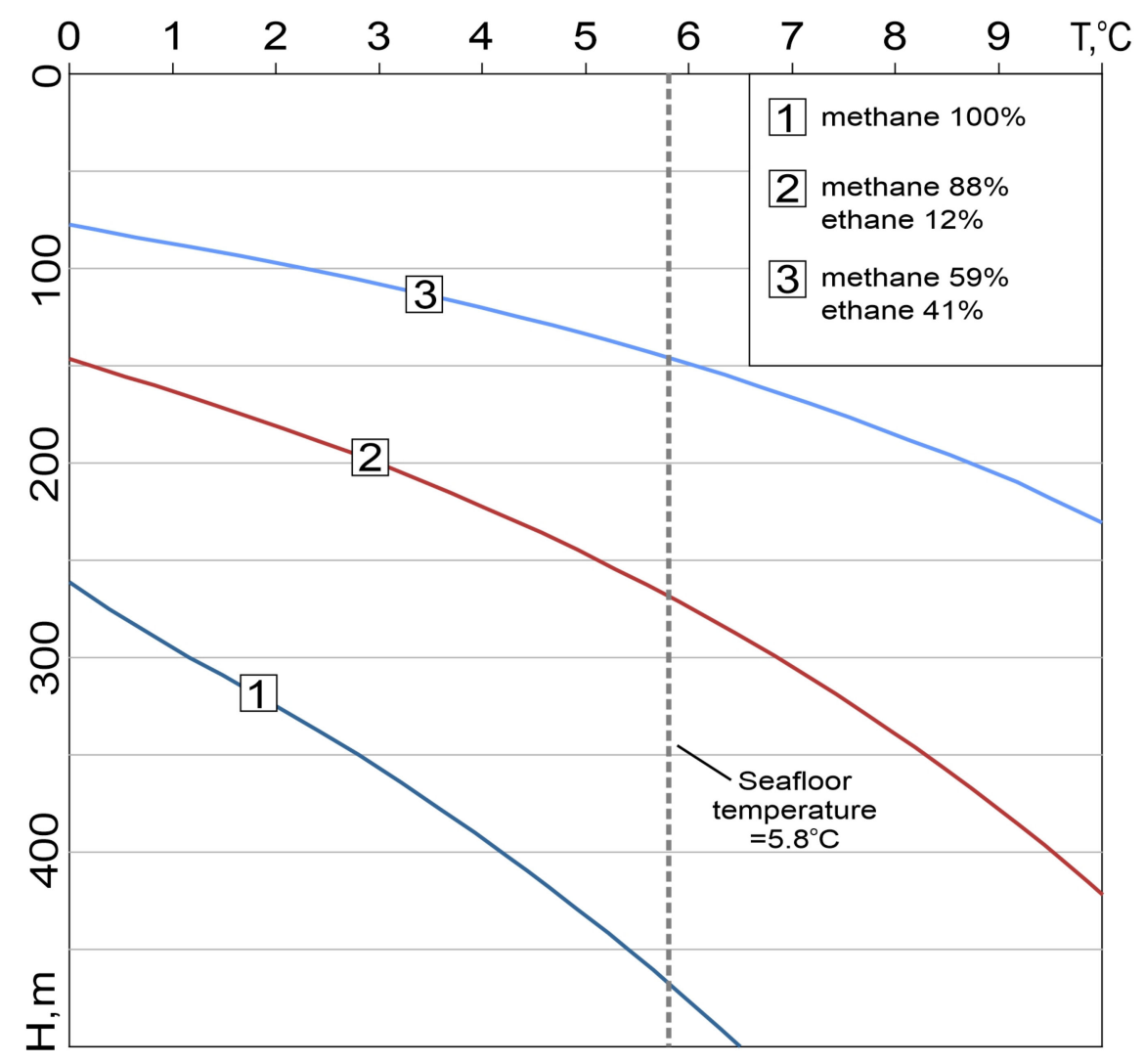

Figure 5. Phase equilibrium diagram for a system of fresh water and different hydrocarbon gas compositions based on pure methane (1) and gas compositions with ethane $(2,3)$.

For the SC, maximal predicted GHSZ thickness for a mixture of gases can be significantly larger than those calculated by the authors for methane hydrates (900-956 m). It can reach 1300-1350 $\mathrm{m}[14,41,59]$. Therefore, it is necessary to consider possible threats from GH for drilling in a wide range of water depths and for wells with bottoms down to $1000 \mathrm{~m}$ and deeper. GH might exist in the upper part of sedimentary cover at shallow seafloor depths as isolated local zones, attributed to free gas accumulations with abnormally high formation pressures.

\section{Conclusions}

As a result of studies for the Derbent and Lankaran depressions of the Caspian Sea, on the basis calculation methods using new data, the distribution of methane hydrate stability zones was specified, and cartographic schemes of their thicknesses were created for two models concerning the minimal and maximal forecasts. 
It was revealed that for the South Caspian, conditions for methane hydrates formation exist at bottom depths from $419 \mathrm{~m}$ (model M2) and $454 \mathrm{~m}$ (model M1), whereas for the MC, from $416 \mathrm{~m}$ (M2) and $453 \mathrm{~m}$ (M1).

For the two forecasts, values of the maximal thicknesses of GHSZ vary in the ranges: for the MC, from 226-676 $\mathrm{m}$ in the center of the Derbent Depression; for the SC, from 900-956 $\mathrm{m}$ in the central part of the Lankaran Depression.

Conducted calculations and created maps showed that variations in GG, seafloor depth (pressure), and gas composition can make a strong effect on the GHSZ thickness and change it by several hundreds of meters. This circumstance is necessary to understand when making forecasts of GH potential not only for the Caspian Sea, but also for other regions of the world. For valid calculations of GHSZ, it is crucial to conduct detailed field studies, as well as a thorough investigation of all available geological, geophysical materials and, particularly, data of geochemical analysis of gas composition in the upper part of sedimentary cover of a studied region.

Conducted forecast can be useful for planning engineering studies, construction of facilities of petroleum industry in the Caspian Sea-since the issue of GH presence or absence is substantial for determination of seabed stability-and also for increasing safety of drilling exploratory wells and further HC production.

Author Contributions: V.B. developed methodology, supervised the research, analyzed the results, wrote the manuscript. A.Y. and A.K. collected and processed data using special software, conducted research. All authors have read and agreed to the published version of the manuscript.

Funding: The research was conducted according to the state assignment of OGRI RAS on the topic no. AAAA-A19-119021590079-6.

Institutional Review Board Statement: Not applicable.

Informed Consent Statement: Not applicable.

Data Availability Statement: Publicly available datasets were analyzed in this study. This data can be found here: https: / / www.ncei.noaa.gov/products/world-ocean-database/ (accessed on 30 May 2021); https:/ / www.gebco.net/ (accessed on 30 May 2021).

Acknowledgments: The authors are grateful to NOAA and GEBCO for the provided data, and to the Center for Hydrate Research of Colorado School of Mines for the software.

Conflicts of Interest: The authors declare no conflict of interest.

\section{References}

1. McGlade, C.; Speirs, J.; Sorrell, S. Unconventional gas-A review of regional and global resource estimates. Energy 2013, 55, 571-584. [CrossRef]

2. Ma, Y.Z.; Holditch, S. Unconventional Oil and Gas Resources Handbook: Evaluation and Development; Gulf Professional Publishing: London, UK, 2015.

3. Wallmann, K.; Schicks, J.M. Gas Hydrates as an Unconventional Hydrocarbon Resource. In Hydrocarbons, Oils and Lipids: Diversity, Origin, Chemistry and Fate; Wilkes, H., Ed.; Springer Nature: Cham, Switzerland, 2020; pp. 651-666.

4. Kvenvolden, K.A. A Primer on gas hydrates. In US Geological Survey Professional Paper; U.S. Government Publishing Office: Washington, DC, USA, 1993; Volume 1570, pp. 279-291.

5. Makogon, Y.F.; Omelchenko, R.Y. Messoyakha-The gas hydrate deposit, its role and meaning. Geol. Miner. Resour. World Ocean 2012, 3, 5-19. (In Russian)

6. Bogoyavlensky, V.; Bogoyavlensky, I.; Nikonov, R.; Yakushev, V.; Sevastyanov, V. Permanent Gas Emission from the Seyakha Crater of Gas Blowout, Yamal Peninsula, Russian Arctic. Energies 2021, 14, 5345. [CrossRef]

7. Wu, N.Y.; Huang, L.; Hu, G.W.; Li, Y.L.; Chen, Q.; Liu, C.L. Geological controlling factors and scientific challenges for offshore gas hydrate exploitation. Mar. Geol. Quat. Geol. 2017, 37, 1-11.

8. Wu, N.; Li, Y.; Wan, Y.; Sun, J.; Huang, L.; Mao, P. Prospect of marine natural gas hydrate stimulation theory and technology system. Nat. Gas Ind. B 2021, 8, 173-187. [CrossRef]

9. Bogoyavlensky, V.I. Emergencies in the development of oil and gas resources in the Arctic and the World Ocean. Arct. Ecol. Econ. 2014, 4, 48-59. (In Russian)

10. Sedigh, M.; Vahedi, M.; Khodafarin, R.; Osouli, A. Gas hydrate of deep water regions and drilling hazards. In Proceedings of the 7th International Conference on Gas Hydrates (ICGH 2011), Edinburgh, UK, 17-21 July 2011; Volume 98. 
11. Ejike, C.E. Assessment of Hazards in Gas Hydrates Recovery. Open J. Yangtze Oil Gas 2019, 4, 231-239. [CrossRef]

12. Gao, Y.; Chen, Y.; Zhao, X.; Wang, Z.; Li, H.; Sun, B. Risk analysis on the blowout in deepwater drilling when encountering hydrate-bearing reservoir. Ocean Eng. 2018, 170, 1-5. [CrossRef]

13. Zhang, M.; Niu, M.; Shen, S.; Dai, S.; Xu, Y. Review of natural gas hydrate dissociation effects on seabed stability. Nat. Hazards 2021, 107, 1035-1045. [CrossRef]

14. Diaconescu, C.C.; Knapp, J.H. Gas Hydrates of the South Caspian Sea, Azerbaijan: Drilling Hazards and Sea Floor Destabilizers. In Proceedings of the Offshore Technology Conference, Houston, TX, USA, 6-9 May 2002. Paper Number: OTC-14036-MS. [CrossRef]

15. Vavik, D. Implications of Gas Hydrates in Drilling and Completion A Scientific Root Cause Analysis of the Deepwater Horizon Disaster. Ph.D. Thesis, Norwegian University of Science and Technology, Trondheim, Norway, 2020.

16. Henriet, J.P.; Mienert, J. (Eds.) Gas Hydrates: Relevance to World Margin Stability and Climate Change; Geological Society of London: Bath, UK, 1998.

17. Judd, A.G.; Hovland, M.; Dimitrov, L.I.; Garcia Gil, S.; Jukes, V. The geological methane budget at continental margins and its influence on climate change. Geofluids 2002, 2, 109-126. [CrossRef]

18. Shakhova, N.; Semiletov, I.; Chuvilin, E. Understanding the permafrost-hydrate system and associated methane releases in the East Siberian Arctic shelf. Geosciences 2019, 9, 251. [CrossRef]

19. Bogoyavlensky, V.I.; Kazanin, A.G.; Kishankov, A.V.; Kazanin, G.A. Earth degassing in the Arctic: Comprehensive analysis of powerful gas emission in the Laptev Sea. Arctic Ecol. Econ. 2021, 11, 178-194. (In Russian) [CrossRef]

20. Yefremova, A.G.; Gritchina, N.D.; Kulakova, L.S. Discovery of gas hydrates in the South Caspian. Express Inf. VNIIEGazprom 1979, 21, 12-13. (In Russian)

21. Kvenvolden, K.A. A review of the geochemistry of methane in natural gas hydrate. Org. Geochem. 1995, 23, 997-1008. [CrossRef]

22. Altynov, A.I.; Alyabina, I.O.; Arakcheev, A.N.; Ashik, A.M.; Baburin, V.L.; Badina, S.V.; Barsova, N.Y.; Baryshev, I.B.; Belousov, S.K.; Berdnikov, N.M.; et al. National Atlas of the Arctic; Roskartografiya: Moscow, Russia, 2017. (In Russian)

23. Istomin, V.A.; Yakushev, V.S.; Kvon, V.G.; Dolgaev, S.I.; Chuvilin, E.M. Directions of modern research on gas hydrates. Gas Chem. 2009, 3, 56-63. (In Russian)

24. Duchkov, A.D. Methane gas hydrates in sediments of Lake Baikal. Russ. Chem. J. 2003, 47, 91-100. (In Russian)

25. Bogoyavlensky, V.; Kishankov, A.; Yanchevskaya, A.; Bogoyavlensky, I. Forecast of Gas Hydrates Distribution Zones in the Arctic Ocean and Adjacent Offshore Areas. Geosciences 2018, 8, 453. [CrossRef]

26. Bogoyavlensky, V.I.; Yanchevskaya, A.S.; Bogoyavlensky, I.V.; Kishankov, A.V. Gas hydrates in the Circum-Arctic Region aquatories. Arctic Ecol. Econ. 2018, 3, 42-55. (In Russian) [CrossRef]

27. Bogoyavlensky, V.I.; Kazanin, G.S.; Kishankov, A.V. Gas Saturation of Shallow Deposits of the Arctic and Subarctic Seas. In Proceedings of the Marine Technologies 2019 Conference (European Association of Geoscientists \& Engineers), Gelendzhik, Russia, 22-26 April 2019; pp. 1-7. [CrossRef]

28. Bogoyavlensky, V.I.; Kishankov, A.V.; Yanchevskaya, A.S.; Bogoyavlensky, I.V. Gas hydrates potential of the Arctic and Caspian Offshore Areas. In Proceedings of the Third International Conference on Geology of the Caspian Sea and Adjacent Areas (European Association of Geoscientists \& Engineers), Baku, Azerbaijan, 16-18 October 2019; pp. 1-5. [CrossRef]

29. Bogoyavlensky, V.I.; Yanchevskaya, A.S. Features of the Earth Degassing and Gas Hydrates Distribution in the Black Sea. In Proceedings of the Geomodel 2020 Conference (European Association of Geoscientists \& Engineers), Gelendzhik, Russia, 7-11 September 2020. [CrossRef]

30. Ginsburg, G.D.; Gramberg, I.S.; Guliyev, I.S.; Guseinov, R.A.; Dadashev, A.A.; Ivanov, V.L.; Krotov, A.G.; Muradov, C.S.; Soloviev, V.A.; Telepnev, Y.V. Gas-hydrate accumulations of submarine mud-vulcano type. Trans. USSR Acad. Sci. 1988, 300, $416-418$. (In Russian)

31. Huseynov, D.A.; Guliyev, I.S. Mud volcanic natural phenomena in the South Caspian Basin: Geology, fluid dynamics and environmental impact. Environ. Geol. 2004, 46, 1012-1023. [CrossRef]

32. Huseynov, R.A.; Dadashev, F.G. Hydrocarbon Gases of the Caspian Sea; Nafta-Press: Baku, Azerbaijan, 2000. (In Russian)

33. Guliyev, I.S.; Huseynov, D.A. Relics of mud volcanoes in the sedimentary cover of the South Caspian Basin. Lithol. Miner. Resour. 2015, 50, 311-321. [CrossRef]

34. Obzhirov, A.I.; Telegin, Y.A.; Shakirov, R.B.; Salomatin, A.S.; Derkachev, A.N.; Syrbu, N.S.; Li, N.S.; Ponomareva, A.L.; Es'kova, A.I. Methane Flows and Gas Hydrates in the Transition Zone Between the Western Slope of the Kuril Basin and Offshore from Sakhalin Island. Russ. J. Pac. Geol. 2020, 14, 591-600. [CrossRef]

35. Meazell, P.K.; Flemings, P.B.; Santra, M.; Johnson, J.E. Sedimentology and stratigraphy of a deep-water gas hydrate reservoir in the northern Gulf of Mexico. AAPG Bull. 2020, 104, 1945-1969. [CrossRef]

36. Vogt, P.R.; Cherkashev, G.; Ginsburg, G.; Ivanov, G.; Milkov, A.; Crane, K.; Lein, A.; Sundvor, E.; Pimenov, N.; Egorov, A. Haakon Mosby mud volcano provides unusual example of venting. EOS Trans. Am. Geophys. Union 1997, 78, 549-557. [CrossRef]

37. Skorobogatko, A.N. Possibility of formation of hydrates of hydrocarbon gases in the upper part of the sedimentary strata of the Caspian Sea. Geol. Oil Gas 1983, 3, 46. (In Russian)

38. Babaev, A.S. Regularities of the location of accumulations of gas hydrates in the Caspian Sea. Sci. Technol. Gas Ind. 2016, 3, 46-51. (In Russian) 
39. Glumov, I.F.; Malovichkiy, Y.P.; Novikov, A.A.; Senin, B.V. Regional Geology and Oil and Gas Potential of the Caspian Sea; NedraBusiness Center: Moscow, Russia, 2004. (In Russian)

40. Poletaev, A.V.; Poletaeva, E.V. Estimation of volumes of hydrocarbon gases of gas hydrates of the Azerbaijan South sector according to seismic data. Bull. Tomsk Polytech. Univ. Georesour. Eng. 2018, 329, 153-162. (In Russian)

41. Diaconescu, C.C.; Kieckhefer, R.M.; Knapp, J.H. Geophysical evidence for gas hydrates in the deep water of the South Caspian Basin, Azerbaijan. Mar. Petr. Geol. 2001, 18, 209-221. [CrossRef]

42. Muradov, C.S. The Area of formation of the South Caspian gas hydrates. In South-Caspian Basin: Geology, Geophysics, Oil and Gas Content; Ali-Zadeh, A.A., Ed.; Nafta-Press: Baku, Azerbaijan, 2004; pp. 322-332.

43. Center for Hydrate Research; Colorado School of Mines. Available online: http:/ /hydrates.mines.edu (accessed on 15 April 2021).

44. CSMHYD. Publicly Available Software. Available online: http://hydrates.mines.edu/CHR/Software.html (accessed on 2 July 2021).

45. Sloan, E.D. Offshore Hydrate Engineering Handbook; Center for Hydrate Research, Colorado School of Mines: Golden, CO, USA, 1998.

46. GEBCO. The General Bathymetric Chart of the Oceans. Available online: https://www.gebco.net/ (accessed on 15 April 2021).

47. World Ocean Database; National Centers for Environmental Information. Available online: https://www.ncei.noaa.gov/ products / world-ocean-database/ (accessed on 15 April 2021).

48. Makarenko, F.A.; Polyak, B.G. (Eds.) Heat Regime of the USSR Interiors, Transactions, Volume 218; Nauka: Moscow, Russia, 1970 (In Russian)

49. Ginsburg, G.D.; Guseynov, R.A.; Dadashev, A.A.; Ivanova, G.A.; Kazantsev, S.A.; Solov'yev, V.A.; Telepnev, E.V.; Askeri-Nasirov, R.Y.e.; Yesikov, A.D.; Mal'tseva, V.I.; et al. Gas hydrates of the southern Caspian. Int. Geol. Rev. 1992, 34, 765-782. [CrossRef]

50. Schoellkopf, N.B.; Dahl, J.E. Geochemistry and Maturation History of the South Caspian Basin, Azerbaijan; Chevron Internal Report; CIS: Minsk, Belarus, 1995.

51. Tagiyev, M.F.; Nadirov, R.S.; Bagirov, E.B.; Lerche, I. Geohistory, thermal history and hydrocarbon generation history of the north-west South Caspian Basin. Mar. Pet. Geol. 1997, 14, 363-382. [CrossRef]

52. Abasov, M.T.; Aliyarov, R.Y.; Kondrushkin, Y.M.; Krutykh, L.G.; Mustafayev, R.T.; Rakhmanova, I.S. Thermobaric regime of a section of the South-Caspian sedimentary basin fields. In South-Caspian Basin: Geology, Geophysics, Oil and Gas Content; Ali-Zadeh, A.A., Ed.; Nafta-Press: Baku, Azerbaijan, 2004; pp. 165-172.

53. Mukhtarov, A.S. Heat flow distribution and some aspects of formation of thermal field in the Caspian Region. In South-Caspian Basin: Geology, Geophysics, Oil and Gas Content; Ali-Zadeh, A.A., Ed.; Nafta-Press: Baku, Azerbaijan, 2004; pp. 165-172.

54. Zui, V.; Mansouri Far, S. Geothermal field and geology of the Caspian Sea region. J. Belarusian State Univ. Geogr. Geol. 2019, 1, 104-118. [CrossRef]

55. Devlin, W.J.; Cogswell, J.M.; Gaskins, G.M.; Isaksen, G.H.; Pitcher, D.M.; Puls, D.P.; Stanley, K.O.; Wall, G.R.T. South Caspian Basin-Young, cool, and full of promise. Geol. Soc. Am. Today 1999, 83, 12.

56. Reiner, S. Ocean. Data View. 2021. Available online: odv.awi.de (accessed on 30 May 2021).

57. Poletayev, A.V. Gas Hydrates of the Southern Caspian. Oceanology 2020, 60, 682-690. [CrossRef]

58. Moukhtarov, F. Core Sample Report; Chevron Internal Report: Aberdeen, Scotland, 1998.

59. Diaconescu, C.C.; Knapp, J.H. Buried Gas Hydrates in the Deepwater of the South Caspian Sea, Azerbaijan: Implications for Geo-Hazards. Energy Explor. Exploit. 2000, 18, 385-400. [CrossRef]

60. Guliyev, I.S.; Mamedov, P.Z.; Feyzullayev, A.A.; Huseynov, D.A.; Kadirov, F.A.; Aliyeva, E.H.-M.; Tagiyev, M.F. Hydrocarbon Systems of the South Caspian Basin; Nafta-Press: Baku, Azerbaijan, 2003. 